Вісник Дніпропетровського університету. Біологія. Екологія. - 2010. - Вип. 18, т. 1. - С. $52-57$. Visnyk of Dnipropetrovsk University. Biology. Ecology. - 2010. - Vol. 18, N 1. - P. 52-57.

УДК 612.397:678.012+579.6

М. О. Кісякова, Г. П. Гаврилюк, О. С. Воронкова, О. А. Сірокваша, А. І. Вінніков

Дніпропетровський національний університет ім. Олеся Гончара

\title{
ЛІПОСОМИ: СТРУКТУРА, ВЛАСТИВОСТІ, СПОСОБИ ВВЕДЕННЯ В ОРГАНІЗМ ІЗ ТЕРАПЕВТИЧНОЮ МЕТОЮ
}

Проаналізовано дані літератури, присвячені питанням будови, властивостей та процесу утворення ліпосом. Розглянуто переваги ліпосом при застосуванні їх у медицині. Охарактеризовано способи введення ліпосом у організм. Узагальнено дані про механізми взаємодії ліпосом із клітинами, особливості ліпідного складу ліпосом і залежність від цього їх тропності до певних органів і тканин.

М. А. Кисякова, А. Ф. Гаврилюк, О. С. Воронкова, Е. А. Сирокваша, А. И. Винников Днепропетровский национальный университет им. Олеся Гончара

\section{ЛИПОСОМЫ: СТРУКТУРА, СВОЙСТВА, СПОСОБЫ ВВЕДЕНИЯ В ОРГАНИЗМ С ТЕРАПЕВТИЧЕСКИМИ ЦЕЛЯМИ}

Проанализированы данные литературы, посвященные вопросам строения, свойств и процесса образования липосом. Рассмотрены преимущества липосом при использовании их в медицине. Охарактеризованы способы введения липосом в организм. Обобщены данные о механизмах взаимодействия липосом с клетками, особенности липидного состава липосом и зависимость от этого их тропизма к определенным органам и тканям.

M. A. Kisyakova, A. F. Gavrilyuk, O. S. Voronkova, E. A. Sirokvasha, A. I. Vinnikov Oles' Honchar Dnipropetrovsk National University

\section{LIPOSOMES: STRUCTURE, PROPERTIES AND METHODS OF CURATIVE ADMINISTRATION IN ORGANISM}

A review of data from scientific sources, devoted to problems of liposomes' structure, properties and processes of formation was made. Advantages of liposomes used for medical purposes are shown. Methods of liposomes administration in an organism are characterised. Data on mechanisms of interaction between liposomes and cells, peculiarities of liposomes' lipids composition and dependence of its tropism to definite organs and tissues are generalised.

\section{Ветуп}

Більшість сучасних лікарських препаратів, вживаних у традиційних формах, досить обмежено проникає через клітинні біомембрани і після надходження до організму піддається істотній біотрансформації, унаслідок чого втрачає свою фармакологічну активність. Саме тому на сьогодні при розробці нових лікарських засобів увага дослідників зосереджена на вивченні можливості збільшити здатність препаратів легко проникати через бар'єри біомембран у клітини-мішені [2]. 


\section{Ліпосоми: будова та властивості}

Термін «ліпосома» (лат. - «ліпідне тіло») стосується будь-яких ліпідних бішарових структур, вміст яких - водний розчин будь-якої речовини $[1 ; 3 ; 5]$. Це поширена модель біологічних мембран. Ліпосоми являють собою замкнені сферичні пухирці, утворені 3 амфіфільних речовин, таких як фосфоліпіди (дифільність або амфіфільність, тобто здатність одних частин макромолекули віддавати перевагу, наприклад, полярному оточенню, а інших - неполярному). При взаємодії з водними розчинами ці речовини самоорганізуються у двошарові мембрани.

Термін «мікрокапсули» для визначення ліпосом чи фосфоліпідних везикул (ФЛВ) запропоновано Д. Осто в 1970-ті роки [12]. Пік розвитку цього напряму припадає на 1980-ті роки, коли було запатентовано основні методи одержання найрізноманітніших фосфоліпідних везикул (ФЛВ) [9]. Деякі ліпідні везикули отримали спеціальні назви, наприклад, протеоліпосоми, імуносоми, віросоми [11].

Ліпосоми - сферичні ліпідні везикули, до складу яких звичайно входять різні фосфоліпіди (фосфатидилхолін, фосфатидилсерин і фосфатидилетаноламін), специфічні глікопептиди, а також холестерин, який $є$ стероїдним компонентом практично всіх клітинних мембран. Захисною «парасолькою» ліпосом, що забезпечує їх стабільність і тривалу циркуляцію в крові, найчастіше $є$ поліетиленгліколь (ПЕГ) та його похідні.

Важливі характеристики ліпосом - ліпідний склад, середній діаметр і ступінь гетерогенності за розмірами. Про розподіл ліпосом за розміром можна судити за даними гельпроникної хроматографії, світлорозсіювання, ультрацентрифугування, електронної мікроскопії [14].

Особливий інтерес для тих, хто досліджує здатність ліпосом містити в собі різні речовини, становлять такі параметри: внутрішній водний об'єм (кількість водорозчинної речовини у розрахунку на 1 моль ліпіду), ефективність включення (частка водного об'єму, включеного всередину везикул). Перший параметр збільшується зі зростанням діаметра ліпосом, другий прямо пропорційний концентрації ліпіду.

Властивості ліпосом та їх поведінка визначаються насамперед наявністю в них замкнутої мембранної оболонки [16]. Деякі властивості ліпосом, такі як рідинні властивості мембрани, розмір, поверхневий заряд, залежать від ліпідного складу й технології виготовлення.

Незважаючи на молекулярну товщину (близько 4 нм), ліпідний бішар відрізняється винятковою механічною міцністю та гнучкістю. Гнучкість бішару додає ліпосомам високої пластичності. Так, ліпосоми змінюють розміри та форму у відповідь на зміну осмотичної концентрації зовнішнього водного розчину. При сильному осмотичному стресі цілісність може порушитися, і ліпосоми можуть роздрібнитися на частинки менших розмірів. При відповідному доборі ліпідних компонентів утворяться стабільні пухирці, які тривалий час за температури тіла не ушкоджуються в сироватці, зберігаючи свій фармакологічно активний вміст [11]. Другою важливою властивістю біомембран, яку добре модулюють ліпосоми, $є$ проникність для різних сполук. Проникність ліпосомальної мембрани залежить від іï фазового стану; вона особливо велика поблизу температури фазового переходу фосфоліпідів ліпосоми, коли молекули в мембрані максимально не впорядковані [7; 11]. Для практичного застосування ліпосом і везикул винятково важлива їх здатність включати в себе й утримувати речовини різної природи. Коло речовин, що можуть бути включеними до ліпосом, надзвичайно широке від неорганічних іонів і низькомолекулярних органічних сполук до великих білків і 
нуклеїнових кислот $[1 ; 5 ; 6]$. Водорозчинні препарати потрапляють до їх внутрішньої фази, а ліпофільні сполуки включаються до бішарової мембрани $[1 ; 3]$.

\section{Механізм утворення ліпосом}

Формування ліпосом відбувається таким чином: фосфоліпіди при диспергуванні у воді (або органічних розчинниках) утворюють гетерогенну суміш везикулярних структур, що складається з декількох бішарових конщентричних оболонок.

Молекула фосфоліпіду складається 3 полярної (голівки) та неполярної (хвіст жирної кислоти) частин. У водному розчині голівки фосфоліпідів експонуються назовні (у водний розчин), а хвости обернені всередину, у результаті чого утворюються мембранні везикули.

Неорганічні іони, присутні в розчині в момент набрякання фосфоліпідів, включаються всередину цих частинок й утримуються там тривалий час, обмінюючись 3 іонами зовнішнього розчину з дуже малою швидкістю. Так уперше було встановлено, що фосфоліпіди, які є основними компонентами клітинних мембран, здатні спонтанно утворювати у воді замкнені мембранні оболонки. Ці оболонки захоплюють у себе частину навколишнього водного розчину, а фосфоліпідна мембрана, що їх утворює, має властивості напівпроникного бар'єра, який легко пропускає воду, але перешкоджає дифузії розчинених у ній речовин [11].

Ліпосоми отримують як із природних, так і з синтетичних фосфоліпідів. Кожен із методів дозволяє не тільки отримати ліпосоми різних розмірів і з різною кількістю концентричних бішарів, а й включати до них різноманітні хімічні сполуки та біологічно активні молекули. Як правило, у вихідну ліпідну суміш вводять додатково холестерол (іноді до 40 \%), що надає мембранам підвищеної міцності. Водорозчинні речовини входять до внутрішнього водного об'єму ліпосом. Наявність у бішарі достатньо довгої вуглеводневої ділянки дозволяє вводити до нього гідрофобні молекули. На поверхні бішару можна адсорбувати різні хімічні речовини, а також хімічно зв'язувати їх із ліпідами або іншими компонентами мембрани.

\section{Способи уведення ліпосом до організму та особливості їх взаємодії з клітинними мембранами}

Сьогодні відомо декілька способів уведення ліпосом до організму (оральний, парентеральний, внутрішньом'язовий), але у будь-якому разі ліпосоми будуть взаємодіяти 3 мембранами клітин різних тканин. Залежно від цього ліпідний склад ліпосом може варіювати. Методи реконструкції мембранних систем базуються на їх злитті та утворенні міжклітинних контактів. Процеси злиття мембран вивчали 3 використанням ліпосом, що дозволило встановити цілу низку закономірностей. Встановлено, що ліпідні бішари можуть мимовільно зливатися, якщо вони перебувають у щільному контакті. Процес «перезамкнення» мембран проходить у дві стадії: у першій виникає перемичка (сталк) між найближчими моношарами, яка розширюється, формуючи контактний бішар. На другій стадії відбувається перехід від напівзлиття до повного злиття в результаті руйнування контактного бішару, чому сприяє позитивна спонтанна кривизна віддалених моношарів і підвищений поверхневий натяг.

Припускають, що злиття мембран ініціюється змінами в їх структурі у результаті виникнення при наближенні ліпосом одна до одної внутрішньомембранного електричного поля, яке створюється зарядженими групами ліпідів. Такі зміни можна спрямовано індукувати з використанням УЗО, детергентів та органічних розчинників, а також 
уведенням до системи іонів $\mathrm{Ca}^{2+}$, який нейтралізує поверхневий заряд мембранних фосфоліпідів, утворюючи з ними комплекс у співвідношенні $1: 4$ [11].

Усі зовнішні чинники, які змінюють плинність бішару мембрани, наприклад, механічне напруження, детергенти, осмотичний тиск, наявність іонів, здатні впливати на процеси злиття як штучних, так і клітинних мембран.

Важливим є питання як можуть взаємодіяти мембрани ліпосоми 3 іншими бішаровими ліпідними мембранами. Припускають, що мембрани можуть взаємодіяти за такими принципами:

- по-перше, шляхом неповного злиття ліпосом із бішаровими ліпідними мембранами 3 утворенням бішару-гібриду (зовнішня мембрана ліпосоми та моношар БЛМ);

- по-друге, шляхом повного включення ліпосом та їх ділянок у бішарову мембрану;

- по-третє, вмонтовуванням ліпосом до бішару;

- по-четверте, за рахунок адгезії. Адсорбція ліпосом на мембранних бішарах відбувається за рахунок електростатичних сил. Під час злиття між контактуючими мембранами або виникає перемичка, або відбувається руйнування моношарів усередині утвореної структури $[10 ; 11]$.

Результат взаємодії ліпосом із тканинами організму багато в чому залежить від способу введення.

При оральному способі ліпосоми руйнуються у травному тракті при низьких значеннях $p H$, ліпазами та детергентною дією жовчних солей. Уведення у кров звичайно приводить до їх захоплення клітинами ретикуло-ендотеліальної системи, переважним чином макрофагами печінки та селезінки. Одразу ж після уведення ліпосоми адсорбуються на найближчій поверхні або вкриваються білками плазми (вірогідно, переважно альбумінами). Вони також можуть викликати агрегацію негативно заряджених клітин.

Після внутрішньовенного уведення катіонні ліпосоми виходять із системи циркуляції за декілька хвилин $[19 ; 22]$. Відповідно до даних експериментів із радіоактивним міченням [10] більша частина їх акумулювалася в легенях. Однак кількість ліпосом значно зменшувалася (через 1 годину - $18 \%$, через 1 добу $-2,5 \%$ ); фракція у серці достовірно не змінювалась (5\%), у той час як у селезінці вона зростала (14\% через 1 годину, $20 \%$ через 4 години та $18 \%$ через 1 добу).

При парентеральному введенні розподіл ліпосом у організмі залежить від складу ліпосомальної мембрани, їх розміру, заряду, інших хімічних і фізичних параметрів везикул та іммобілізованих у них речовин, а також від способу введення. Після підшкірного введення значна кількість ліпосом депонується в місці введення та елімінується звідти переважно лімфогенним шляхом. Таким чином, місцеве введення ліпосомальних препаратів - оптимальний спосіб їх доставки до регіонарних лімфовузлів [15; 17]. При внутрішньом'язовому введенні ліпосоми здатні створювати депо препарату у місці введення, швидкість елімінації з депо залежить від розміру та властивостей ліпосом і складає період від декількох годин (якщо ліпосоми дрібні) до декількох діб (якщо великі). Дрібні бішарові ліпосоми, на відміну від великих, при внутрішньочеревному або внутрішньом'язовому введенні значно швидше проникають у кровообіг, що вказує на обмежену здатність останніх проходити крізь капіляри та мембрани судин [18]. При внутрішньовенному введенні дрібні ліпосоми виводяться 3 кровообігу повільніше, ніж великі [20].

Для підвищення тропності ліпосом до певних органів і тканин їх виготовляють із фосфоліпідів, ізольованих із цих органів, або фіксують на поверхні специфічні антитіла проти відповідних тканинних антигенів, чи застосовують так звані молекули- 
посередники, що мають два типи спорідненості: з одного боку - до клітин макроорганізму, а з іншого - до ліпосоми [8]. Ліпіди беруть певну участь у «розпізнаванні» клітин, оскільки кожному типу мембран відповідає визначене, характерне лише для нього співвідношення полярних ліпідів [13; 15].

У процесі «розпізнавання» важливу роль відіграють також гліколіпіди (гангліозиди), що беруть участь у міжклітинних взаємодіях і $є$ специфічними рецепторами ряду біологічно активних сполук [4]. Тобто механізм взаємодії ліпосом із клітинами визначають не лише фосфоліпіди, а й гангліозиди, що входять до складу ліпосом. Вивчення розподілу ліпосом, які містять фосфатидилхолін, холестерин і гліколіпід, при внутрішньовенному введенні в організм показало, що найкращими гліколіпідами для ліпосом відносно їх переносу в тканини головного мозку та печінки є сульфатид, у тканини селезінки - гангліозиди, у тканини легень - сфінгомієлін [8]. Наприклад, людський $\alpha$-інтерферон, іммобілізований у ліпосоми, мембрана яких побудована 3 фосфатидилхоліну, холестерину та сульфатиду, після внутрішньочеревного введення переважно буде знайдений у крові, печінці, селезінці й пухлинній тканині мозку [21].

\section{Висновки}

Ліпосоми - ліпідні утворення, перспективні для введення до організму різних білків, зокрема ферментів (при ензимотерапії) та цитокінів (для корекції імунного статусу організму), антибіотиків, токсичних хіміопрепаратів для терапії раку тощо. Важливими характеристиками ліпосом є ліпідний склад, середній діаметр і ступінь гетерогенності за розмірами. Рідинні властивості мембрани, розмір, поверхневий заряд залежать від ліпідного складу й технології виготовлення ліпосом. Існують дані про можливість уведення ліпосом до організму оральним, парентеральним і внутрішньочеревним шляхом. Тропність ліпосом до певних органів і тканин залежить від їх ліпідного складу. Ліпосоми - перспективні носії для спрямованої доставки лікарських засобів, тому що вони малотоксичні та здатні до біодеградації.

Основні напрями діяльності в галузі застосування ліпосом - фундаментальні дослідження проникності двошарових мембран ліпосом, вивчення підвищення стабільності й однорідності їх складу, а також технологічні розробки з метою здешевлення та удосконалення виробництва ліпосомальних форм лікарських препаратів.

\section{Бібліографічні посилання}

1. Барсуков Л. И. Липосомы // Сорос. образов. журн. - 1998. - № 10. - С. 12-19.

2. Барсуков Л. И. Как собрать мембрану (Солюбилизация и реконструкция мембран) // Сорос. образов. журн. - 2004. - № 1. - С. 34-39.

3. Варпаховская И. Липосомальные формы лекарственных средств // Ремедиум. - 1999. - № 5. C. 26-34.

4. Ганглиозиды - рецепторы бактериальных токсинов и других биологически активных веществ / В. И. Ефременко, Н. И. Нарбутович, Н. Ф. Ходова и др. // Аннотированный библиографический указатель отечественной и зарубежной литературы 1976-1986 гг. - Волгоград : Б. и., 1988. - С. 202.

5. Карпушина И. А. Применение методики направленного транспорта лекарственных веществ в клинической практике / И. А. Карпушина, Т. Ф. Стеблева, Е. Ю. Бонитенко // Токсикология. 2004. - Т. 5, № 12. - С. 39-46.

6. Кобринский Г. Липосомы в медицине // Наука и жизнь. - 1988. - № 6. - С. 23-30.

7. Костюк О. П. Физиологические и терапевтические свойства лактобактерий / О. П. Костюк, Л. И. Чернышова, А. П. Волоха // Педиатрия. - 1998. - № 1. - С. 71-76. 
8. Медикаментозное преодоление анатомических и клеточных барьеров с помощью липосом / Под ред. Л. М. Кузяковой, В. И. Ефременко. - Ставрополь : Б. и., 2000. - 170 с.

9. Мосійчук С. М. Пробіотики: можливість застосування при гіперхолестеринемії / С. М. Мосійчук, М. Б. Хоменко // Український медичний часопис. - 2006. - № 2. - С. 10-24.

10. Невирусный перенос генов in vivo в генной терапии / Е. В. Богданенко, Ю. В. Свиридов, А. А. Московцев и др. // Вопросы медицинской химии. - 2000. - № 3. - С. 27-33.

11. Остапченко Л. І. Біологічні мембрани: методи дослідження структури та функцій / Л. І. Остапченко, І. В. Михайлик. - К. : Київський ун-т, 2006. - 215 с.

12. Осто М. Д. Липосомы // В мире науки. - 1987. - № 3. - С. 56-62.

13. Саатов Т. С. Аутологичные липосомы / Т. С. Саатов, Э. И. Исаев, С. А. Бурханов // Вестн. АМН СССР. - 1990. - № 8. - С. 47-50.

14. Тенденции в развитии исследований в области липосом: обзор патентной литературы / Н. Ю. Несытова, Н. С. Палева, Е. В. Ильина и др. // Вест. АМН СССР. - 1990. - № 10. - С. 8-29.

15. Шраер Т. И. Направленный транспорт липосом в условиях ауто- и аллотрансплантации / Т. И. Шраер, С. Б. Семченко // Тез. докл. II Рос. национ. конгресса «Человек и лекарство». M., 1995. - С. 292.

16. Эванз У. Г. Биологические мембраны. Методы // Под ред. Д. Б. Финдлея. - М. : Мир, 1990. $424 \mathrm{c}$.

17. Юлиш Е. И. Липосомальная терапия: настоящее и будущее / Е. И. Юлиш, А. Е. Абатуров // Здоровье ребенка. - 2008. - № 1 (10). - С. 20-28.

18. Dapergolas G. Penetration of target areas in the rat by liposome - associated bleomycin, glucose oxidase and insulin / G. Dapergolas, E. D. Neerunjun, G. Gregoriadis // FEBS Lett. - 1976. - Vol. 63. P. 235-239.

19. Goren D. Targeting of stealth liposomes to er-B2 (Her/2) receptor: In vitro and in vivo studies / D. Goren, A. T. Horowitz, S. Zalipsky // Br. J. Cancer. - 1996. - Vol. 74. - P. 1749-1756.

20. Juliano B. L. The effect of particle size and change on the clerance rates of liposomes and liposome encapsulated drugs / B. L. Juliano, D. Stamp // Biochem. Biophys. Res. Com. - 1975. - Vol. 63. P. 651-658.

21. Kato K. Liposome - entrapped human interferon- $\beta$ / K. Kato, J. Yoshida et al. // J. Clin. Biochem. and Nutr. - 1988. - Vol. 4, N 2. - P. 139-147.

22. Tissue distribution of the cytofectin component of a plasmid-DNA/cationic lipid complex following intravenous administration in mice / O. Rosengarten, A. T. Horowitz, D. Tzemach et al. // Cancer Gene Ther. - 1994. - Vol. 1. - P. 301-336. 